\title{
Update on clinical inflammometry for the management of airway diseases
}

\author{
Parameswaran Nair MD PhD FRCP FRCPC
}

\begin{abstract}
P Nair. Update on clinical inflammometry for the management of airway diseases. Can Respir J 2013;20(2):117-120.
\end{abstract}

\begin{abstract}
Airway inflammation is a central feature of many airway diseases such as asthma, chronic bronchitis, bronchiectasis and chronic cough; therefore, it is only logical that it is measured to optimize its treatment. However, most treatment recommendations, including the use of anti-inflammatory therapies such as corticosteroids, are based on assessments of only airflow and symptoms. Over the past 10 years, methods have been developed to assess airway inflammation relatively noninvasively. Quantitative cell counts in sputum and the fraction of exhaled nitric oxide are the most validated tests. Judicious use of currently available drugs, such as corticosteroids, bronchodilators and antibiotics, and other anti-inflammatory therapies guided by sputum eosinophil and neutrophil counts, have been demonstrated to decrease exacerbations of asthma and chronic obstructive pulmonary disease, ameliorate cough, improve quality of life in patients with these diseases and is cost effective compared with treatment strategies based on guidelines that do not incorporate these measurements. Thus, it is unfortunate that this is not used more widely in the management of airway diseases, particularly in patients with severe asthma and chronic obstructive pulmonary disease who experience frequent exacerbations.
\end{abstract}

Key Words: Asthma; COPD; Cough; Exhaled nitric oxide; Inflammometry; Sputum

\begin{abstract}
$A$ irway mucosal inflammation is fundamental to the etiology and A persistence of asthma (1) and other airway diseases such as smoker's bronchitis, emphysema, chronic cough and bronchiectasis. It contributes to symptoms, variable airflow limitation and airway hyperresponsiveness and the structural changes (ie, remodelling) associated with asthma. The presence and type of airway inflammation can be difficult to detect clinically, delaying the introduction of appropriate treatment (2). However, until recently, its measurement was not considered by national and international guidelines that recommended treatment based only on symptoms and measurement of airflow. The Canadian Thoracic Society pioneered the introduction of these measurements in the management of chronic obstructive pulmonary disease (COPD) (3) and asthma (4) in the most recent iteration of their guidelines. The present review will summarize the methods that are currently under evaluation for the measurement of airway inflammation in clinical practice and discuss the practical implementation of quantitative sputum cell counts in the management of asthma, COPD and chronic cough as practiced at the Firestone Institute of Respiratory Health at St Joseph's Healthcare in Hamilton, Ontario, for the past 20 years. The present update does not review indirect measures of airway inflammation such as mannitol (Aridol, Pharmaxis, Australia) hyper-responsiveness.
\end{abstract}

\footnotetext{
METHODS TO ASSESS AIRWAY INFLAMMATION Sputum

Sputum cell counts are a relatively noninvasive and reliable method of identifying airway inflammation. The method of sputum collection is well described and standardized (5). Hypertonic saline inhalation is safe in patients with forced expiratory volume in $1 \mathrm{~s}\left(\mathrm{FEV}_{1}\right)$ as low as $0.9 \mathrm{~L}$ (6). Spontaneously expectorated sputum, when available, provides
}

\author{
Mise à jour sur l'inflammométrie clinique pour \\ prendre en charge les maladies des voies respiratoires
}

L'inflammation des voies respiratoires est un élément central de nombreuses maladies des voies respiratoires comme l'asthme, la bronchite chronique, la bronchiectasie et la toux chronique. Par conséquent, il est logique de la mesurer pour en optimiser le traitement. Cependant, la plupart des recommandations thérapeutiques, y compris le recours à des traitements anti-inflammatoires comme les corticoïdes, se fondent sur des évaluations limitées au débit respiratoire et aux symptômes. Depuis dix ans, des méthodes ont été mises au point pour évaluer l'inflammation des voies respiratoires de manière relativement non envahissante. Le dénombrement cellulaire quantitatif dans les expectorations et la fraction de monoxyde d'azote exhalé sont les tests les plus validés. Il est démontré qu'une utilisation judicieuse des médicaments sur le marché, tels que les corticoïdes, les bronchodilatateurs et les antibiotiques, et d'autres traitements antiinflammatoires sélectionnés selon la numération des éosinophiles et des neutrophiles dans les expectorations, réduit les exacerbations d'asthme et de maladie pulmonaire obstructive chronique, limite la toux, améliore la qualité de vie chez les patients atteints de ces maladies et est rentable par rapport à des stratégies thérapeutiques fondées sur des lignes directrices qui n'intègrent pas ces mesures. Il est donc malheureux qu'on ne l'utilise pas de manière plus généralisée pour traiter les maladies des voies respiratoires, notamment chez les patients atteints d'asthme grave et de maladie pulmonaire obstructive chronique qui présentent de fréquentes exacerbations.

information equally as useful as induced sputum (7). The method is successful in almost all patients with smoker's bronchitis and COPD, in $80 \%$ of patients with asthma and in $60 \%$ of patients with a dry, chronic cough (8). Sputum processing and the quantification of cell counts are also standardized (9), and normal values have been established (10). It has recently been simplified by the introduction of a commercially available sputum filtration device (Accufilter, Cellometrics, Canada) and a kit (11). The cell counts can accurately discriminate eosinophilic airway inflammation from noneosinophilic airway inflammation. Eosinophilic airway inflammation is steroid responsive (12) while noneosinophilic (usually neutrophilic) inflammation generally is not (13). Monitoring of airway inflammation using sputum cell counts helps to identify impending loss of asthma control and adjust anti-inflammatory medications in patients with a variety of airway diseases such as asthma, smoker's bronchitis and chronic cough. It helps to increase corticosteroid dosing in exacerbations associated with an eosinophilic bronchitis, limit the use of corticosteroids in exacerbations associated with a noneosinophilic bronchitis and use antibiotics in exacerbations associated with a neutrophilic bronchitis. This also helps to identify patients with an 'eosinophil phenotype' for targeted therapy with anti-eosinophil strategies such as anti-interleukin 5 molecules (14), and to develop protocols to investigate patients with persistent eosinophilic (15) or neutrophilic bronchitis (16). Such treatment strategies help to significantly reduce asthma exacerbations $(17,18)$ and hospitalizations due to exacerbations of COPD (19). Sputum examination provides additional useful information in patients with airway diseases. For example, macrophages containing hemosiderin can be useful in detecting left ventricular dysfunction (20), and macrophages containing lipid are suggestive of oropharyngeal reflux with microaspiration (21), both of which can complicate

Firestone Institute for Respiratory Health, St Joseph's Healthcare Hamilton and the Department of Medicine, McMaster University, Hamilton,

Ontario

Correspondence: Dr Parameswaran Nair, Firestone Institute for Respiratory Health, 50 Charlton Avenue East, St Joseph's Healthcare Hamilton,

Hamilton, Ontario L8N 4A6. Telephone 905-522-1155 ext 35044, fax 905-521-6183, e-mail parames@mcmaster.ca 


\section{TABLE 1}

\section{Adjustment of treatment based on sputum cell count}

\begin{tabular}{|c|}
\hline Eosinophilic bronchitis \\
\hline$>3 \%$ increase steroid dose even if asymptomatic \\
\hline $2 \%-3 \%$, or EFGs, increase if symptomatic \\
\hline $1 \%-2 \%$ dose unchanged \\
\hline $0 \%-1 \%$ consider reducing dose \\
\hline Evaluate for prednisone-sparing therapy \\
\hline Neutrophilic bronchitis \\
\hline TCC $>25 \times 10^{6} / \mathrm{g}, \mathrm{N}>80 \%$ antibiotics \\
\hline TCC $10 \times 10^{6} / \mathrm{g}-25 \times 10^{6} / \mathrm{g}, \mathrm{N}>80 \%$ consider antibiotics \\
\hline TCC $<10 \times 10^{6} / \mathrm{g}$ OR isolated $\mathrm{N}>80 \%$ no antibiotics \\
\hline TCC $>60 \times 10^{6} / \mathrm{g}, \mathrm{N}>80 \%$ bronchiectasis \\
\hline Recheck sputum 4-6 weeks after treatment change \\
\hline Add LABA after controlling bronchitis \\
\hline Same strategy for COPD, hemosiderin in M $\Theta$ to assess LVEDP \\
\hline Same strategy for chronic cough, lipid in $\mathrm{M} \Theta$ to assess reflux \\
\hline
\end{tabular}

COPD Chronic obstructive pulmonary disease; EFG Eosinophil-free granules; LABA Long-acting beta-agonist; LVEDP Left ventricular end-diastolic pressure;

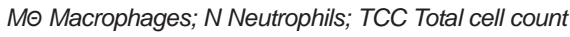

or confuse assessment of airway disease. The major limitation of sputum cell counts, despite its elaborate validation methods, is the need for a laboratory, which limits its accessibility. The development of a point-of-care test to assess eosinophil or neutrophil activity will likely facilitate more widespread use of sputum measurements in clinical practice.

\section{Exhaled nitric oxide}

This measurement, which is a reflection of the activity of the nitric oxide synthase enzyme, is perhaps the most widely used assessment of airway inflammation in clinical practice today. A United States Food and Drug Administration-approved device (Niox, Aerocrine, Sweden) is available commercially, and the measurement is very well standardized and normal values have been established (22). However, it does not help to identify the cellular nature of airway inflammation associated with exacerbations of airway diseases, particularly in patients who are already being treated with corticosteroids. Thus, it may be a predictor of steroid responsiveness, but does not help to reduce asthma exacerbations (23) when used in clinical practice, except in patients with mild airway disease (24). It may be an alternative measurement in patients who are unable to produce sputum; however, this requires more investigation.

Exhaled breath measurements (mediators, pH, temperature) Two commercially available devices (EcoScreen [Jaeger GmbH, Germany], RT tubes [Respiratory Research, USA]) are widely used to collect breath condensate. An array of cytokines, mediators and growth factors have been measured that appear to discriminate, with a reasonable degree of accuracy, between healthy and diseased states (25). Although breath condensate $\mathrm{pH}$, which considers the relationship among airway acidification, buffering capacity and inflammation, is the most rigorously validated measurement and may provide some information regarding airway inflammation (ie, low $\mathrm{pH}$ representing an inflamed airway), it is not yet ready to be useful for monitoring therapy and anticipating inflammatory lung disease exacerbations in individual patients. However, this measurement holds promise, with the primary advantage being that it is totally noninvasive and can be applied to children. Temperature measurement in exhaled air, which is a reflection of mucosal blood flow, is also now possible with a commercially available instrument (X-halo, Delmedica, Singapore). While it has the advantage of being easy to use and may discriminate between healthy volunteers and patients with airway diseases (26), it is too early to apply to clinical practice to monitor disease, adjust medications or discriminate among severities of bronchitis.
Metabolomics in breath and in urine

The analysis of volatile organic compounds in exhaled breath using gas chromatography and mass spectrometry (electronic-Nose) is a novel, attractive and completely noninvasive technology that is currently being evaluated to assess airway inflammation. Volatile compounds that are identified are analyzed using statistical methods, such as principal component analysis, using a systems biology approach to recognize patterns consistent with physiological or pathological abnormalities. It remains a research tool that has shown that it can discriminate between eosinophilic and neutrophilic bronchitis in patients with asthma and with COPD (27). The technology is currently undergoing evaluation for possible application in routine clinical practice.

A similar approach is being developed to analyze metabolites in urine. Urine metabolites, analyzed using nuclear magnetic resonance spectroscopy, discriminate between children with asthma and those with other obstructive airway diseases, including infective bronchitis and pneumonia (28). This technology is particularly attractive because it can be applied in subjects as young as one day of age because urine can be obtained from diapers or catheters. It remains to be determined whether a metabolomics approach to measurements in breath condensate or in urine would be useful tests that can be applied routinely in clinical practice.

\section{Clinical practice in Hamilton}

Spontaneous sputum is collected from patients with airway diseases (eg, chronic cough, COPD, asthma, bronchiectasis) at the time of initial assessment and at the time of every exacerbation. In practical terms, these are patients who are usually already being treated with moderate to high doses of inhaled corticosteroids and a long-acting beta-agonist. They fall into one of three categories: patients who require daily or frequent courses of prednisone; patients who experience recurrent 'bronchitis'; and patients who experience frequent 'exacerbations'. If the patient is not able to produce sputum spontaneously, it is induced by the inhalation of hypertonic saline in the pulmonary function laboratory as a routine, scheduled test. Pre- and post-salbutamol spirometry are recorded, and the patient susequently inhales 3\%, $4 \%$ and $5 \%$ saline solutions, each for $7 \mathrm{~min}$, delivered through a low-output ultrasonic nebulizer with a particle size of approximately 3 to 4 mass median aerodynamic diameters. $\mathrm{FEV}_{1}$ is measured after each concentration is inhaled and the flow-volume curves are carefully inspected for evidence of vocal cord dysfunction. If the $\mathrm{FEV}_{1}$ drops by $15 \%$, salbutamol is administered and the time taken for the $\mathrm{FEV}_{1}$ to return to preinduction baseline is recorded. Failure of salbutamol to protect against saline-induced bronchoconstriction and the refractoriness to bronchodilation are interpreted as indicators of possible tolerance to the bronchoprotective effects of beta-agonists (or moderate airway hyper-responsiveness) and increased mast cell activity, respectively. Sputum is transported to a combined clinical/research laboratory that operates under the Hamilton Regional Laboratory Medicine program, where it is processed within $15 \mathrm{~min}$ to $20 \mathrm{~min}$ and a result is made available within $2 \mathrm{~h}$. The spirometry and sputum cell counts are captured in a database (approximately 12,000 to date) and the results (with a clinical interpretation) are made available to the referring physician at the end of the day. Patients are then telephoned the same evening or the next day with recommendations based on the sputum cell counts (Table 1). The same approach is now being evaluated to treat rhinitis based on processing of cell counts in blown nasal secretions (29).

\section{CONCLUSIONS}

Clinical guidelines and regulatory agencies have begun to recognize the importance of measuring bronchitis to optimize the management of airway diseases and to guide anti-inflammatory therapies. Of the currently available methods, quantitative cell counts in sputum and exhaled nitric oxide are well validated and recommended by professional organizations for clinical use. Sputum cell counts have the advantage of providing information about the cellular nature of 
TABLE 2

Information obtained from the process of sputum collection and examination

\begin{tabular}{l} 
Sputum induction \\
Airflow obstruction \\
Vocal cord dysfunction \\
Hyper-responsiveness \\
Tolerance to bronchodilators \\
Sputum examination \\
Infection: Bacterial versus nonbacterial \\
Eosinophilic bronchitis \\
Microaspiration \\
Left ventricular dysfunction \\
Possible postnasal drip \\
Environmental exposures, cigarette smoking \\
Helps design protocols to investigate types of bronchitis \\
\hline
\end{tabular}

bronchitis in patients with all ranges of severity of airway diseases, but have the disadvantage of limited accessibility. Although sputum holds promise of being able to measure proteome (30) and transcriptome (31), currently, these measures are not validated to be used as routine clinical tools to make treatment decisions for asthma or for COPD. In addition to information related to bronchitis, the process of sputum collection provides additional information on airflow obstruction, airway hyper-responsiveness and possible beta-receptor subsensitivity (Table 2). Its use in clinical practice is partly limited by misconceptions related to its implementation and interpretation (Table 3), which can be easily overcome. Because sputum cell count-based treatment strategies are more effective than any other currently available

\section{REFERENCES}

1. Djukanovic R, Roche WR, Wilson JW, et al. Mucosal inflammation in asthma. Am Rev Respir Dis 1990;142:434-57.

2. Nair P, Pizzichini E, Pizzichini MM, Hussack P, Efthimiadis A, Hargreave FE. Clinical judgement of airway inflammation versus sputum cell counts in patients with asthma. Eur Respir J 2000;15:486-90.

3. O'Donnell DE, Aaron S, Bourbeau J, et al. Canadian Thoracic Society recommendations for management of chronic obstructive pulmonary disease - 2007 update. Can Respir J 2007;14(Suppl B): 5B-32B.

4. Lougheed MD, Lemiere C, Ducharme FM, et al. Canadian Thoracic Society 2012 guideline update: Diagnosis and management of asthma in preschoolers, children and adults. Can Respir J 2012;19:127-64.

5. Popov TA, Pizzichini MM, Pizzichini E, et al. Some technical factors influencing the induction of sputum for cell analysis. Eur Respir J 1995;8:559-65.

6. Vlachos-Mayer H, Leigh R, Sharon RF, Hussack P, Hargreave FE. Success and safety of sputum induction in the clinical setting. Eur Respir 2000;16:997-1000.

7. Pizzichini MM, Popov TA, Efthimiadis A, et al. Spontaneous and induced sputum to measure indices of airway inflammation in asthma. Am J Respir Crit Care Med 1996;154:866-9.

8. D'silva L, Hassan N, Wang HY, et al. Heterogeneity of bronchitis in airway diseases in tertiary care clinical practice. Can Respir J 2011;18:144-8.

9. Kelly MM, Efthimiadis A, Hargreave FE. Induced sputum: Selection method. Methods Mol Med 2001;56:77-91

10. Belda J, Leigh R, Nair P, O'Byrne PM, Sears MR, Hargreave FE. Induced sputum cell counts in healthy adults. Am J Respir Crit Care Med 2000;161:475-8.

11. Chaboillez S, Dasgupta A, Prince P, Boulet LP, Lemiere C. A kit to facilitate and standardize the processing of sputum for measurements of airway inflammation. Can Respir J 2013 (In press).

12. Kelly MM, Leigh R, Jayaram L, Goldsmith CH, Nair P, Hargreave FE. Eosinophilic bronchitis in asthma: A model for establishing dose-response and relative potency of inhaled corticosteroids. J Allergy Clin Immunol 2006;117:989-94.

\section{TABLE 3}

Some common misconceptions about sputum cell counts

\section{Sputum should always be induced}

No, spontaneous sputum can be used for reliable cell counts

2. Sputum eosinophilia diagnoses asthma

It does not. It simply identifies the bronchitic component of an airway disease

\section{It is all about eosinophils}

Sputum neutrophil count provides valuable information about the presence of infective bronchitis

\section{Only a single examination is needed}

No, because the nature of inflammation changes over time, sputum must be examined at each exacerbation

\section{Sputum needs to be examined in all patients with airway diseases}

No, only in severe patients not responding to usual therapy or exacerbating frequently

medications for the treatment of asthma or COPD in decreasing exacerbations and hospitalizations (32), and because the majority of physicians and patients consider them useful and necessary (33), we are doing our patients with severe asthma and COPD a disservice by delaying the introduction of sputum cell counts in clinical practice.

DISCLOSURES: Dr Nair is supported by a Canada Research Chair in Airway Inflammometry. This review is a reflection of more than 20 years of research program in Hamilton pioneered by Dr Jerry Dolovich and Dr Freddy Hargreave, and the many clinical fellows who trained under their supervision. The author is listed on a patent for a 'biological fluid filtration device' and has provided scientific consultation to Cellometrics Inc.

13. Green RH, Brightling CE, Woltmann G, Parker D, Wardlaw AJ, Pavord ID. Analysis of induced sputum in adults with asthma: Identification of subgroup with isolated sputum neutrophilia and poor response to inhaled corticosteroids. Thorax 2002;57:875-9.

14. Nair P, Pizzichini MM, Kjarsgaard M, et al. Mepolizumab for prednisone-dependent asthma with sputum eosinophilia. N Engl J Med 2009;360:985-93.

15. Nair P, Ochkur SI, Protheroe C, Simms E, Lee NA, Lee JJ. The identification of eosinophilic gastroenteritis in prednisonedependent eosinophilic bronchitis and asthma. Allergy Asthma Clin Immunol 2011;7:4.

16. Pallan S, Mahony JB, O'Byrne PM, Nair P. Asthma management by monitoring sputum neutrophil count. Chest 2008;134:628-30.

17. Jayaram L, Pizzichini MM, Cook RJ, et al. Determining asthma treatment by monitoring sputum cell counts: Effect on exacerbations. Eur Respir J 2006;27:483-94.

18. Green RH, Brightling CE, McKenna S, et al. Asthma exacerbations and sputum eosinophil counts: A randomised controlled trial. Lancet 2002;360:1715-21.

19. Siva R, Green RH, Brightling CE, et al. Eosinophilic airway inflammation and exacerbations of COPD: A randomised controlled trial. Eur Respir J 2007;29:906-13.

20. Leigh R, Sharon RF, Efthimiadis A, Hargreave FE, Kitching AD. Diagnosis of left-ventricular dysfunction from induced sputum examination. Lancet 1999;354:833-4.

21. Nair P, Anvari M, Efthimiadis A, Kamada D, Hargreave FE, Allen CJ. Lipid-laden macrophages in induced sputum are a marker of oropharyngeal reflux and possible gastric aspiration.

Eur Respir J 2000;16:1119-22.

22. Dweik RA, Boggs PB, Erzurum SC, et al; for the American Thoracic Society Committee on Interpretation of Exhaled Nitric Oxide Levels (FENO) for Clinical Applications. An official ATS clinical practice guideline: Interpretation of exhaled nitric oxide levels (FENO) for clinical applications. Am J Respir Crit Care Med 2011:184:602-15.

23. Smith AD, Cowan JO, Brassett KP, Herbison GP, Taylor DR. Use of exhaled nitric oxide measurements to guide treatment in chronic asthma. N Engl J Med 2005;352:2163-73. 
24. Powell H, Murphy VE, Taylor DR, et al. Management of asthma in pregnancy guided by measurement of fraction of exhaled nitric oxide: A double-blind, randomised controlled trial. Lancet 2011;378:983-90.

25. Davis MD, Montpetit A, Hunt J. Exhaled breath condensate: An overview. Immunol Allergy Clin North Am 2012;32:363-75.

26. Popov TA, Dunev S, Kralimarkova TZ, Kraeva S, DuBuske LM. Evaluation of a simple, potentially individual device for exhaled breath temperature measurement. Respir Med 2007;101:2044-50.

27. Fens N, Roldaan AC, van der Schee MP, et al. External validation of exhaled breath profiling using an electronic nose in the discrimination of asthma with fixed airways obstruction and chronic obstructive pulmonary disease. Clin Exp Allergy 2011;41:1371-8.

28. Adamko DJ, Sykes BD, Rowe BH. The metabolomics of asthma: Novel diagnostic potential. Chest 2012;141:1295-302.

29. Nair P, Goodwin S, Hargreave FE. Reproducibility, validity, and responsiveness of cell counts in blown nasal secretions. Allergy Rhinol 2011;2:3-5.
30. Gharib SA, Nguyen EV, Lai Y, Plampin JD, Goodlett DR, Hallstrand TS. Induced sputum proteome in healthy subjects and asthmatic patients. J Allergy Clin Immunol 2011;128:1176-84.e6.

31. Qiu W, Cho MH, Riley JH, et al; for the ECLIPSE Investigators. Genetics of sputum gene expression in chronic obstructive pulmonary disease. PLoS One 2011;6:e24395.

32. Nair P. Targeted therapy of eosinophils. In: Rosenberg H, Lee JJ, eds. Eosinophils in Health and Disease. London: Elsevier Publishers, 2012:462-6.

33. D'silva L, Neighbour H, Gafni A, Radford K, Hargreave F, Nair P. Quantitative sputum cell counts to monitor bronchitis: A qualitative study of physician and patient perspectives. Can Respir J 2013;20:47-51. 


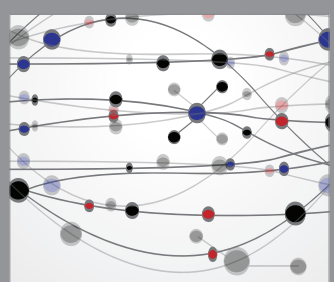

The Scientific World Journal
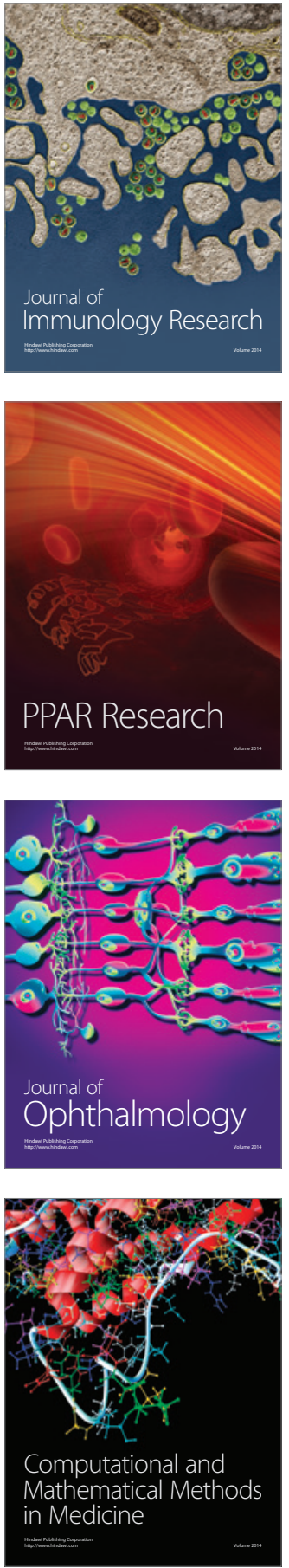

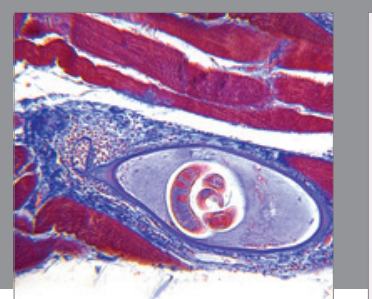

Gastroenterology Research and Practice

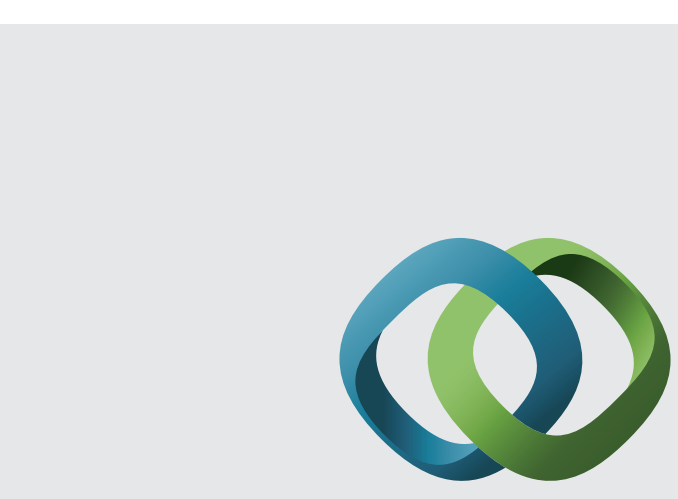

\section{Hindawi}

Submit your manuscripts at

http://www.hindawi.com
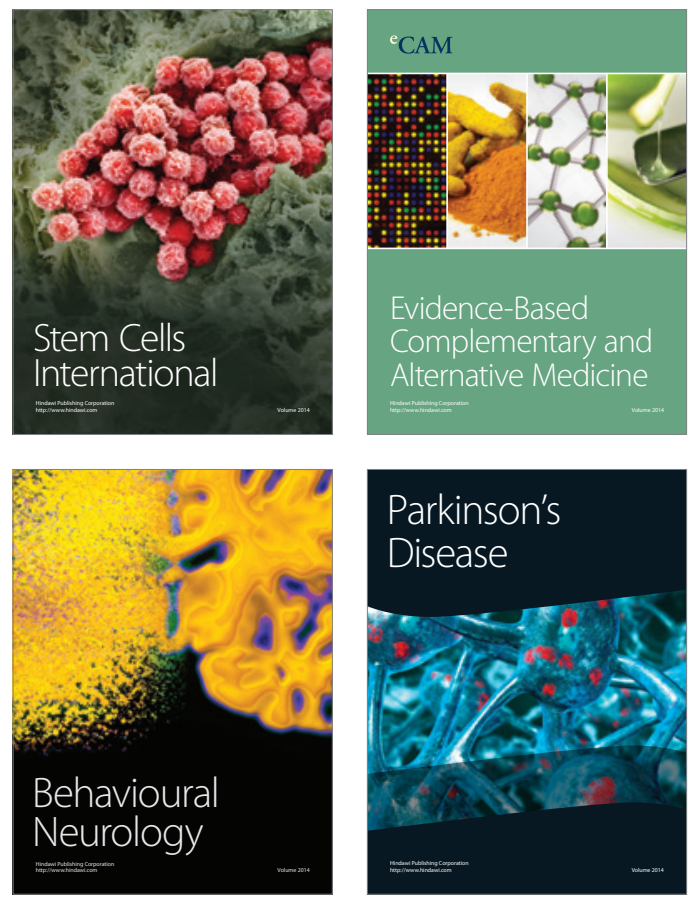
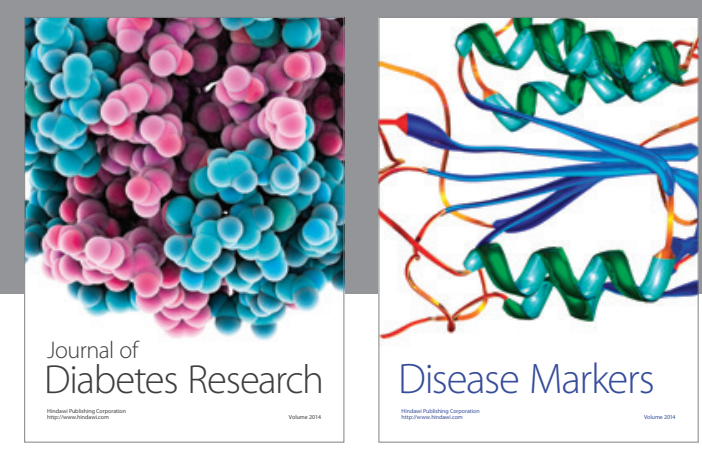

Disease Markers
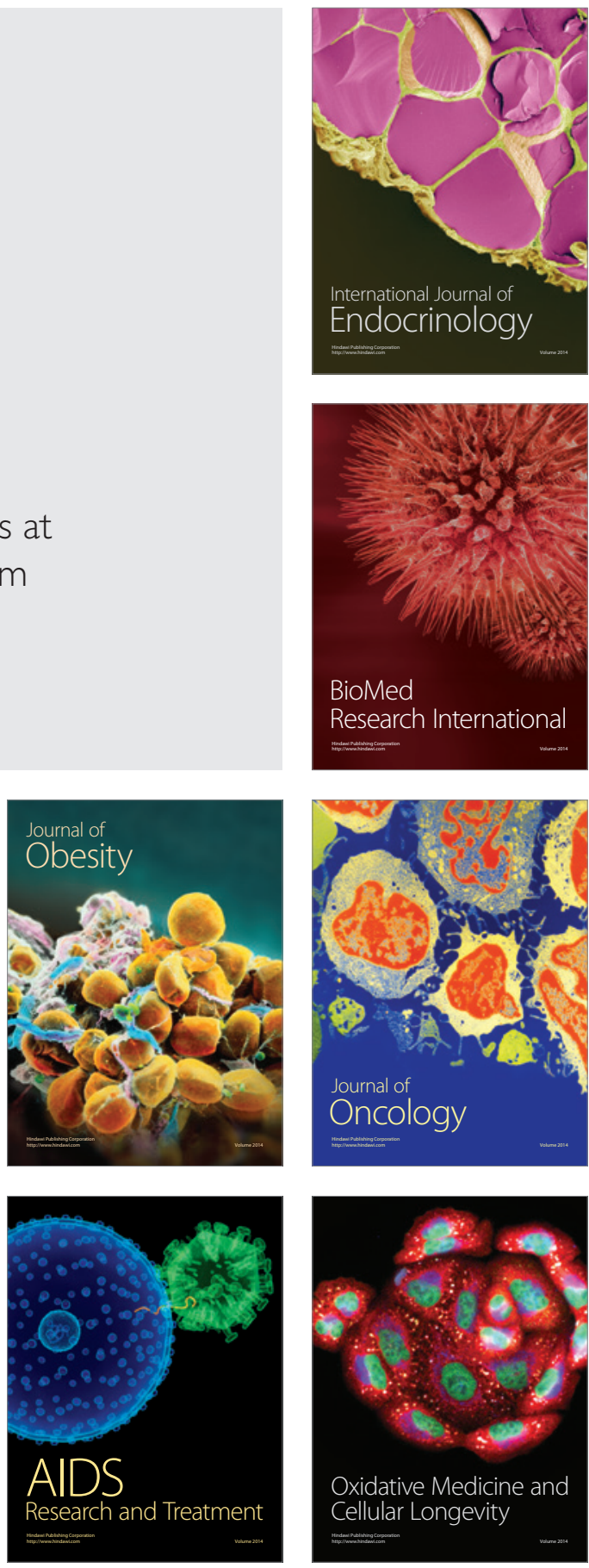